\title{
Maturity stage at harvest and storage temperature to maintain postharvest quality of acerola fruit
}

\author{
Bruna Silva Ribeiro, Sergio Tonetto de Freitas $*$ \\ Brazilian Agricultural Research Corporation, Embrapa, Rodovia BR 428, KM 152, Zona Rural, C.P. 23, Petrolina, PE, Brazil, Brazil
}

\section{A R T I C L E I N F O}

\section{Keywords:}

Malpighia emarginata D.C.

Ripening

Consumer

Chilling injury

Super-fruit

\begin{abstract}
A B S T R A C T
Acerola (Malpighia emarginata D.C.) is native to Central and Northern South America and is considered a superfruit due to its high vitamin $\mathrm{C}$ content. Acerola postharvest life is highly dependent on the maturity stage at harvest and storage temperatures. The objectives of this study were to determine the ideal harvest maturity and storage temperature for 'Flor Branca' and 'Junko' acerolas produced in the São Francisco Valley in the Northeast of Brazil. Acerolas 'Flor Branca' and 'Junko' were harvested at maturity stages green (green skin color at 18 days after full bloom), turning (initial skin color changes from green to red at 20 days after full bloom) and red (red skin color at 22 days after full bloom) and were stored at 8,10 and $12{ }^{\circ} \mathrm{C}$ with $\mathrm{RH}$ of $90-95 \%$ for 14 days. Green fruit with density lower than $1 \mathrm{~g} \mathrm{~cm}^{-3}$ were used due to the capacity to change skin color from green to red after harvest. Fruit harvested at maturity stage green showed better storage potential than fruit harvested at more advanced stages. Storage temperatures of $10^{\circ} \mathrm{C}$ for 'Flor Branca' and $12{ }^{\circ} \mathrm{C}$ for 'Junko' acerolas harvested at maturity stage green maintained fruit quality without chilling injury, keeping the fruit greener with higher ascorbic acid content and flesh firmness during 14 days of storage. Lower storage temperatures resulted in chilling injury incidence in 'Flor Branca' and 'Junco' acerolas. In both acerola cultivars, harvest at maturity stage green resulted in lower fruit decay incidence and weight loss during 14 days of storage. According to the results, 'Flor Branca' and 'Junco' acerolas should be harvested the maturity stage green with density lower than $1 \mathrm{~g} \mathrm{~cm}^{-3}$ and stored at $10^{\circ} \mathrm{C}$ and $12{ }^{\circ} \mathrm{C}$, respectively, in order to maintain high fruit quality.
\end{abstract}

\section{Introduction}

Acerola (Malpighia emarginata D.C) is a tropical species, native to the Caribbean Islands and adapted to the Northeast region of Brazil (Ritzinger and Ritzinger, 2011). The fruit is considered a super-fruit due its high ascorbic acid content that can reaches up to $5 \%$ in the flesh (Mezadri et al., 2006), representing about 80 times the concentrations found in oranges and lemons (Rekha et al., 2012; Ancos et al., 2016; Cunha et al., 2014).

Acerola quality and storage potential are highly dependent on the maturity stage at harvest and storage temperatures (Braman et al., 2015). Therefore, ideal maturity stage at harvest should take into account fruit quality and time required for consumption (Siddiqui and Dhua, 2010; Chen et al., 2017). Fruit harvested at less advanced maturity stages have higher storage capacity and higher ascorbic acid content. However, early harvest limits fruit carbohydrate accumulation and reduces volatiles synthesis responsible for the characteristic aroma of the fruit (Vendramini and Trugo, 2000). On the other hand, fruit harvested at more advanced maturity stages have higher carbohydrate accumulation and synthesis of volatiles, but shorter postharvest life (Siddiqui, 2015a, b).

Storage at low temperature is an efficient approach to maintain quality and increase postharvest life by reducing fruit metabolic activity. Ideal storage temperatures slow down various ripening related processes such as respiration, weight loss, softening and decay incidence (Siddiqui, 2015a, b). However, tropical fruit are generally susceptible to physiological disorders caused by low temperatures, known as chilling injury, which causes a series of modifications in normal fruit metabolism that reduces quality (Mustafa et al., 2016). Chilling temperatures change cell membrane integrity, reducing fluidity and performance, which can result in membrane rupture and cell death (Aghdam et al., 2016). The common symptoms of chilling injury in fruit are tissue darkening, superficial depressions, translucent flesh, failure in ripening and normal color development, as well as loss of characteristic flavor and odor (Oliveira and Santos, 2015). Susceptibility to chilling injury is highly dependent on genotype, and previous studies have shown that fruit of the same species, but different genotypes, may have different ideal storage temperatures (Crisosto et al.,

\footnotetext{
* Corresponding author.

E-mail addresses: sergio.freitas@embrapa.br, stonettodefreitas@yahoo.com.br (S.T. de Freitas).
} 
1999). Indeed, ideal storage temperatures for acerolas have been suggested to range from $5{ }^{\circ} \mathrm{C}$ to $15^{\circ} \mathrm{C}$, depending on genotype and environmental growing conditions (Maciel et al., 2004; Araújo et al., 2009).

Although few studies have suggested a wide range of storage temperatures for some acerola genotypes, there is very limited information about the ideal storage temperature and maturity stage at harvest for many other genotypes produced worldwide. Therefore, the ideal harvest maturity and storage temperature for fresh acerola consumption should be evaluated and identified for each genotype and growing conditions in order to avoid qualitative and quantitative losses due to chilling injury or high fruit metabolic activity.

The objectives of this study were to determine the ideal harvest maturity and storage temperature for 'Flor Branca' and 'Junko' acerolas produced in the São Francisco Valley in the Northeast of Brazil.

\section{Material and methods}

'Flor Branca' and 'Junko' acerolas were produced in seven years old plants cultivated under irrigated conditions in a commercial orchard located in the São Francisco Valley, Petrolina, PE, Brazil $\left(09^{\circ} 09^{\prime} \mathrm{S}\right.$ e $40^{\circ} 22^{\prime} \mathrm{W}$ ). The region has an elevation of $365 \mathrm{~m}$ and a Semi-arid climate (BS'W according to KOPPEN) with average annual temperature of $26^{\circ} \mathrm{C}$, rainfall of $500 \mathrm{~mm}$, and relative humidity of $66 \%$. Fruit were harvested early in the morning at three maturity stages based on skin color, where green $=$ green fruit (18 days after full bloom); turning $=$ fruit presenting initial color changes from green to red $(20$ days after full bloom); red = red fruit (22 days after full bloom) (Table 1). A total of $20 \mathrm{~kg}$ of acerola at each maturity stage was harvested from 40 trees. After harvest, the fruit were transported to the Postharvest Laboratory at Embrapa Semi-arid. Green fruit with density lower than $1 \mathrm{~g} \mathrm{~cm}^{-3}$ were used in the study due to the capacity to change skin color from green to red after harvest. Latter, fruit presenting mechanical damage, diseases and insect damage were eliminated and the remaining fruit treated with chlorinated water containing $600 \mu \mathrm{L}^{-1}$ active chlorine for five minutes and dried at $20^{\circ} \mathrm{C}$ to inhibit decay development. This chlorine concentration was determined in previous studies as the best concentration to inhibit decay incidence in these acerola cultivars. Fruit at each maturity stage were then randomized and stored at 8,10 and $12 \pm 0.5^{\circ} \mathrm{C}$, with relative humidity of 90-95\%. Treatments were combinations between maturity stages at harvest and storage temperatures (factorial $3 \times 3$ ), following a completely randomized experimental design. Each treatment was composed by four replications and each replication by $250 \mathrm{~g}$ of fruit. Health fruit were evaluated at harvest and every seven days for 14 days of storage. Fruit analysis was no longer accomplished when samples reached decay incidence $\geq 60 \%$.

\subsection{Chilling injury}

Chilling injury incidence was determined by counting the number of fruit in each sample with chilling injury symptoms, characterized by discoloration and translucent appearance of epidermal tissues (Mohammed, 2011). The results were expressed as percentage of fruit with chilling injury symptoms in each sample.

\subsection{Skin color}

Skin color was analyzed in the equatorial region of each fruit, using a colorimeter model CR-400 (Konica Minolta, Tokyo, Japan). The results were expressed as Hue angle $\left({ }^{\circ} h\right)$ that represents color values ranging from blue $\left(270^{\circ}\right)$, green $\left(180^{\circ}\right)$, yellow $\left(90^{\circ}\right)$ and red $\left(0^{\circ}\right)$ (Mcguire, 1992).

\subsection{Anthocyanins}

Juice samples were extracted from each replication using a domestic centrifuge model RI 1858 (Philips Walita, São Paulo, Brazil). A total of $2 \mathrm{ml}$ of juice was then subjected to light absorbance analysis at $535 \mathrm{~nm}$ using a spectrometer model 50 UV-vis (Varian Cary, Mulgrave, Australia). Total anthocyanin (ANT) content was calculated as described by Francis (1982) and the results expressed as milligrams of total anthocyanins per $100 \mathrm{~g}$ of juice.

\subsection{Ascorbic acid and titratable acidity}

Ascorbic acid (AA) concentration was determined by diluting $0.5 \mathrm{ml}$ of juice in $100 \mathrm{ml}$ solution containing $0.5 \%$ of oxalic acid, which was then titrated with a solution containing $0.02 \%$ of 2,6-dichlorophenol indophenol (DFI) until permanent light pink color development (Strohecker and Henning, 1967). The results were expressed as percentage of AA in the juice. Titratable acidity (TA) was determined in $1 \mathrm{ml}$ of juice diluted in $50 \mathrm{ml}$ of distilled water, which was then titrated with a solution of $0.1 \mathrm{~N} \mathrm{NaOH}$ until $\mathrm{pH} 8.1$. Titration was performed with a Titrino Plus automatic titrator (Metrohm, São Paulo, Brazil). The AT results were expressed as percent of malic acid present in the juice.

\subsection{Soluble solids}

Soluble solids (SS) were determined in juice samples with a digital refractometer model PAL-1 (Atago, São Paulo, Brazil).

\subsection{Flesh firmness}

Flesh firmness was determined as the maximum force required to press $10 \%$ of the fruit diameter using a TA.XT.Plus texturometer (Extralab $^{\circledast}$, São Paulo, Brazil) adapted with a $\mathrm{P} / 75$ pressure plate. Flesh firmness results were expressed in Newton $(\mathrm{N})$.

\subsection{Decay incidence}

Fruit presenting the visual symptoms of decay were counted in each

Table 1

Physicochemical parameters of 'Flor Branca' and 'Junko' acerolas harvested at three different maturity stages (green, turning and red).

\begin{tabular}{|c|c|c|c|c|c|c|c|c|}
\hline \multirow[t]{2}{*}{ Quality parameter } & \multicolumn{4}{|c|}{ 'Flor Branca' } & \multicolumn{4}{|l|}{ 'Junko' } \\
\hline & Green & Turning & Red & CV (\%) & Green & Turning & Red & CV (\%) \\
\hline SC $\left({ }^{\circ} h\right)$ & $117.4 \mathrm{a}^{*}$ & $96.2 \mathrm{~b}$ & $60.8 \mathrm{c}$ & 2.10 & $112.1 \mathrm{a}$ & $56.8 \mathrm{~b}$ & $24.9 \mathrm{c}$ & 10.73 \\
\hline $\mathrm{FF}(\mathrm{N})$ & $79.7 \mathrm{a}$ & $20.5 \mathrm{~b}$ & $13.6 \mathrm{c}$ & 5.48 & $52.9 \mathrm{a}$ & $29.6 \mathrm{~b}$ & $19.2 \mathrm{c}$ & 6.32 \\
\hline SS (\%) & $6.9 \mathrm{~b}$ & $7.1 \mathrm{~b}$ & $7.7 \mathrm{a}$ & 1.40 & $7.6 \mathrm{~b}$ & $7.8 \mathrm{~b}$ & $8.6 \mathrm{a}$ & 2.90 \\
\hline TA (\%) & $1.86 \mathrm{a}$ & $1.67 \mathrm{~b}$ & $1.52 \mathrm{c}$ & 1.45 & $2.11 \mathrm{a}$ & $2.05 \mathrm{ab}$ & $1.88 \mathrm{~b}$ & 3.44 \\
\hline ANT (mg.100 $\left.\mathrm{g}^{-1}\right)$ & $1.74 \mathrm{c}$ & $4.30 \mathrm{~b}$ & $6.79 \mathrm{a}$ & 6.84 & $0.92 \mathrm{c}$ & $1.92 \mathrm{~b}$ & $7.28 \mathrm{a}$ & 4.38 \\
\hline AA $(\%)$ & $3.56 \mathrm{a}$ & $2.59 \mathrm{~b}$ & $2.16 \mathrm{c}$ & 5.76 & $3.91 \mathrm{a}$ & $3.29 \mathrm{~b}$ & $2.77 \mathrm{c}$ & 5.14 \\
\hline
\end{tabular}

* Averages followed by the same letter are statistically equal according to Tukey test (5\%). Skin color (SC), flesh firmness (FF), soluble solids (SS), titratable acidity (TA), total anthocyanins (ANT) and ascorbic acid (AA). 
sample. Later, the number of fruit presenting dacay symptoms were multiplied by 100 and divided by the total number of fruit in each sample. The results were expressed as percentage of fruit with decay symptoms (\%).

\subsection{Weight loss}

In order to determined weight loss, each sample was weighted at harvest and later at 7 and 14 days of storage. The difference between each sample weight at harvest and at 7 or at 14 days of storage was multiplied by 100 and divided by each sample initial weight at harvest. The results were expressed as percentage (\%) of fruit weight loss at 7 and 14 days of storage.

\subsection{Statistical analysis}

At harvest, the only source of variation was maturity stage. During storage, the sources of variation were maturity stage at harvest and storage temperature. The data were submitted to analysis of variance and the averages were compared by Tukey's test (5\%). Chilling injury and decay incidence data were transformed by the equation arc sine $\sqrt{ } \mathbf{x}$ /100. The statistical analyze was carried out using the software ExpDes.pt (Ferreira et al., 2013) from the software R, version 3.2.5 (R Core Team, 2016). The data was also submitted to principal component analysis (PCA) using the software XLSTAT (Addinsoft, NY, USA).

\section{Results and discussion}

The physico-chemical quality of 'Flor Branca' and 'Junko' acerolas were assessed at harvest. Fruit harvested at less advanced maturity stage had greener skin color, higher flesh firmness, as well as higher TA and AA concentrations. 'Flor Branca' and 'Junko' acerolas harvested at more advanced maturity stages had redder skin color, lower flesh firmness, higher SS, SS/TA ratio, as well as higher ANT content (Table 1).

The effect of the interaction between maturity stage at harvest and storage temperature was determined by the analysis of variance for each quality parameter. The significant effect of the interaction was identified considering the p-value $<0.001$.

\subsection{Chilling injury incidence}

The symptoms of chilling injury were characterized by the aqueous and translucent appearance of fruit tissue during storage (Fig. 1).

The chilling injury incidence in acerola was significantly influenced by the interaction between maturity stage at harvest and storage temperature for 'Flor Branca' acerola at 7 and 14 days and for 'Junko' acerola at 14 days of storage (p-value $<0.001$, Figs. $1-3$ ). The results show that 'Flor Branca' and 'Junko' acerolas developed chilling injury only during storage at 8 and $10{ }^{\circ} \mathrm{C}$ (Figs. 1 and 3). Fruit kept at $12{ }^{\circ} \mathrm{C} \mathrm{did}$ not develop chilling injury symptoms during 14 days of storage (Figs. 1 and 3). 'Flor Branca' acerola exhibited chilling injury symptoms if harvested in all three maturity stages and stored at $8{ }^{\circ} \mathrm{C}$ and if harvested at maturity stage green and stored at $10^{\circ} \mathrm{C}$, both for 7 days. After 14 days, chilling injury incidence was observed only in 'Flor Branca' acerola harvested at maturity stage green and stored at $8^{\circ} \mathrm{C}$ (Figs. 1 and 3). The PCA shows that the highest susceptibility to chilling injury was observed in 'Flor Branca' acerola harvested at maturity stage green stored at $8{ }^{\circ} \mathrm{C}$ for 7 and 14 days (Fig. 2). 'Junko' acerola had no chilling injury symptoms after 7 days of storage at all three maturity stages and temperatures. However, after 14 days of storage fruit harvested at all three maturity stages showed chilling injury symptoms at 8 and $10^{\circ} \mathrm{C}$, but not at $12{ }^{\circ} \mathrm{C}$ (Fig. 2). Storage at $8{ }^{\circ} \mathrm{C}$ resulted in higher percentage of fruit with chilling injury than storage at $10^{\circ} \mathrm{C}$ (Fig. 2). Fruit harvested at the maturity stage green showed higher susceptibility to chilling injury at $10{ }^{\circ} \mathrm{C}$ than fruit harvested at more advanced stages (Fig. 2).
The PCA shows that the highest susceptibility to chilling injury was observed in 'Junko' acerola harvested at all three maturity stages stored at $8{ }^{\circ} \mathrm{C}$ for 14 days (Fig. 2).

Acerolas harvested at the most advanced maturity stage presented loss of red color, while fruit harvested at the maturity stages green and turning showed an inability to develop pigmentation together with water-soaked tissues as symptoms of chilling injury. Both cultivars showed greater susceptibility to chilling injury in fruit harvested at maturity stages green and turning, as well as at storage temperatures lower than $10{ }^{\circ} \mathrm{C}$. These results confirm previous studies showing that the combination between maturity stage and storage temperature determines fruit susceptibility to chilling injury. These studies show that chilling injury has different developmental stages, initially changes occur at the membrane level and after physiological changes take place and continue for an excessive period of time resulting in the visual tissue damage and symptoms (Chitarra and Chitarra, 2005). Fruit at different maturity stages respond differently to chilling injury (Qian et al., 2013). Indeed, studies have shown that carambola and mango fruit harvested at less advanced maturity stages are more susceptible to chilling injury than fruit harvested at more advanced stages (Zhao et al., 2009a, b; Chen et al., 2017). The higher susceptibility of less mature fruit to chilling injury has been attributed to lower tissue antioxidant capacity due to the fact that chilling injury symptoms develop in response to tissue oxidative processes (Qian et al., 2012). In addition, it has been suggested that different antioxidant systems can play an important role in reducing ripe fruit susceptibility to chilling injury (Qian et al., 2012).

Temperature is the main environmental factor that can influence the incidence and severity of chilling injury in fruit (Wang, 2009). The lower the storage temperature, the higher the chilling injury incidence and severity in the fruit (Pan et al., 2017). For instance, papaya fruit stored at 6 and $11{ }^{\circ} \mathrm{C}$ showed high incidence of water soaked symptoms of chilling injury, whereas fruit stored at $1{ }^{\circ} \mathrm{C}$ showed inability to ripen after removal from the chilling temperature (Pan et al., 2017). Previous studies have shown that storage temperature for acerola fruit should not be below $6{ }^{\circ} \mathrm{C}$ to avoid chilling injury (Yahia, 2011). However, in our study, temperatures from 8 to $10^{\circ} \mathrm{C}$ exceeded the minimum safe limit for storage of 'Junko' acerolas, mainly at less advanced maturity stages. On the other hand, 'Flor Branca' acerola harvested at maturity stages turning and red can be stored at 8 and $10^{\circ} \mathrm{C}$ for 14 days without leading to chilling injury symptoms in the fruit, suggesting a greater tolerance of this genotype chilling injury. The degree of fruit susceptibility to chilling injury varies among tissues and genotypes and is genetically regulated (Mangrich and Saltveit, 2000; Zhao et al., 2009a, b). Studies have tested different mango cultivars for susceptibility to chilling injury at $4{ }^{\circ} \mathrm{C}$. In these studies, one mango cultivar developed darkening of the bark and flesh, symptom of chilling injury, while slight darkening was observed in the other cultivar, suggesting the role of genetic mechanisms determining fruit susceptibility to chilling injury (Chidtragool et al., 2011).

\subsection{Red color development}

Fruit color $\left({ }^{\circ} \mathrm{h}\right)$ was significantly influenced by the interaction between maturity stages at harvest and storage temperatures for 'Flor Branca' and 'Junko' acerolas stored for 7 and 14 days (p-value $<0.001$, Fig. 4). The observed decrease in ${ }^{\circ} h$ represents color changes from green to yellow and red, which occurred in response to more advanced maturity stage at harvest and higher storage temperature (Figs. 1 and 4). Fruit with chilling injury symptoms showed limited color changes and water-soaked symptoms during storage (Figs. 1 and 4).

'Flor Branca' acerola harvested at maturity stage green and kept at $8^{\circ} \mathrm{C}$ maintained greener skin color during 14 days of storage, compared with fruit harvested at more advanced stage and stored at higher temperatures (Figs. 1 and 4). However, about $20 \%$ of 'Flor Branca' fruit stored at $8{ }^{\circ} \mathrm{C}$ showed chilling injury symptoms after 14 days of storage. 


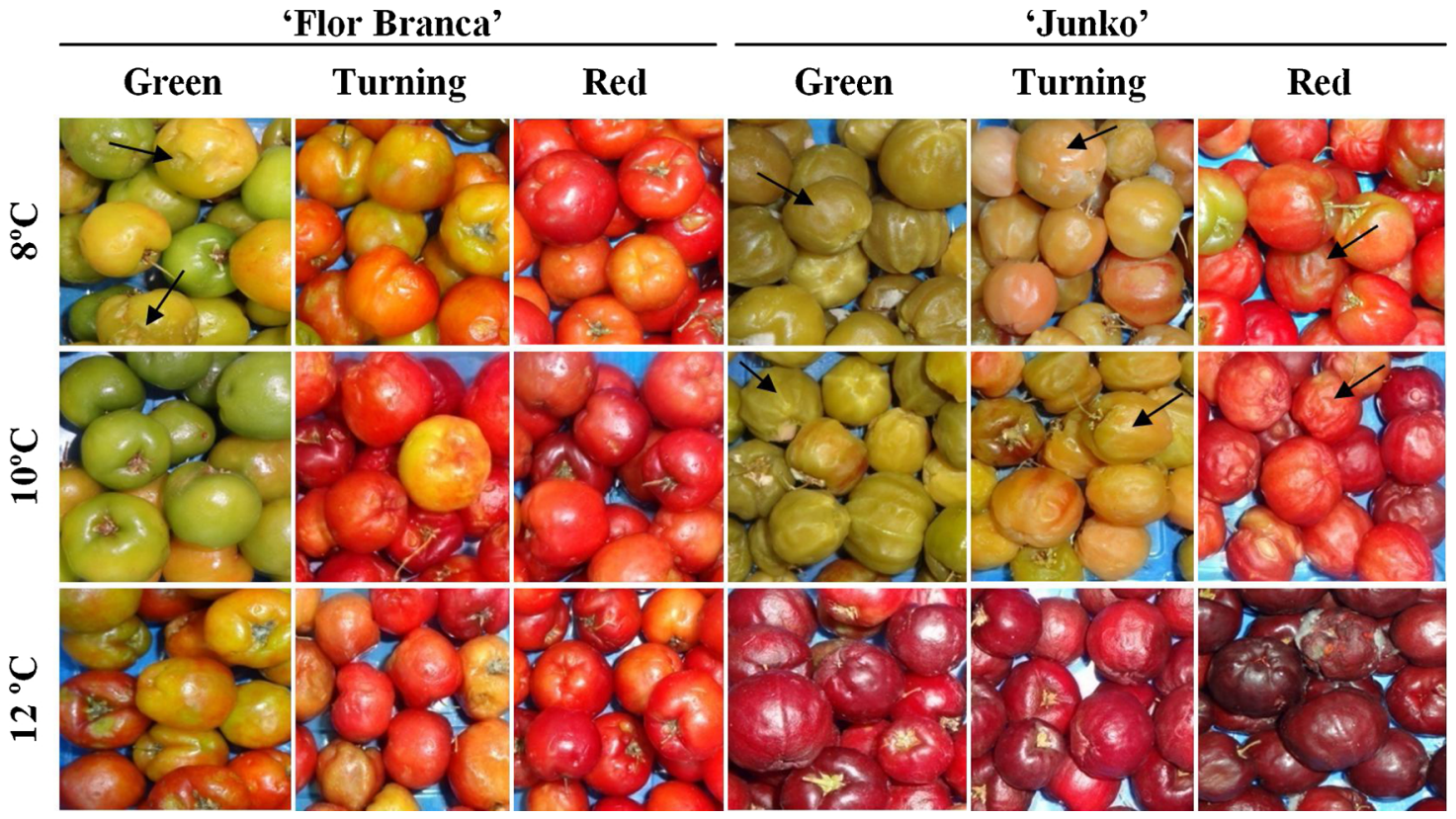

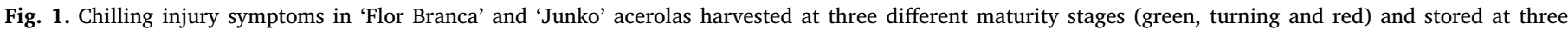
different temperatures $\left(8,10\right.$ and $12{ }^{\circ} \mathrm{C}$ with $\mathrm{RH}$ of $\left.90-95 \%\right)$ for 14 days. Arrows pointing at fruit with chilling injury symptoms.

'Flor Branca' acerola harvested at maturity stage green and stored at 10 and $12{ }^{\circ} \mathrm{C}$ showed the capacity to change color from green to orange and red after 14 days of storage without developing chilling injury symptoms (Figs. 1 and 4). The results also show that 'Flor Branca' acerola harvested at maturity stage green and stored at 10 and $12{ }^{\circ} \mathrm{C}$ had greener skin color than fruit harvested at the turning stage stored at all three temperatures for 14 days, suggesting that harvest at the green stage and storage at 10 and $12{ }^{\circ} \mathrm{C}$ were the most efficient conditions to maintain 'Flor Branca' quality after harvest (Figs. 1 and 4).

'Junko' acerola harvested at the maturity stages green and turning and stored at $12{ }^{\circ} \mathrm{C}$ showed the capacity to change color from green to red after 14 days of storage without developing chilling injury symptoms (Figs. 1 and 4). Fruit harvested at maturity stages green and turning and stored at 8 and $10^{\circ} \mathrm{C}$ showed strong symptoms of chilling injury, presenting limited color changes and water-soaked tissue during 14 days of storage (Figs. 1 and 4). 'Junko' acerola harvested at the red stage had the capacity to change color at all three temperatures, but developed chilling injury during stored at 8 and $10^{\circ} \mathrm{C}$ for 14 days
(Figs. 1 and 4). In that case, harvest at maturity stages green and turning followed by storage at $12{ }^{\circ} \mathrm{C}$ were the most efficient conditions to maintain 'Junko' quality after harvest (Figs. 1 and 4).

The ANT contents of 'Flor Branca' and 'Junko' acerola were significantly influenced by the interaction between maturity stage at harvest and temperature during 7 and 14 days of storage (p-value $<$ 0.001 , Fig. 5). At 7 days, the highest ANT contents were observed in both genotypes harvested at maturity stage red stored at $12{ }^{\circ} \mathrm{C}$ (Fig. 5). At 14 days of storage, the ANT contents were higher in fruit harvested at the maturity stage red stored at 10 and $12{ }^{\circ} \mathrm{C}$ in 'Flor Branca', and at $12{ }^{\circ} \mathrm{C}$ in 'Junko' acerola (Fig. 5). Acerolas of both genotypes harvested at maturity stages green and turning and stored at 8 and $10{ }^{\circ} \mathrm{C}$ exhibited the lowest levels of ANT contents during storage (Fig. 5).

According to the results, acerola ripening was followed by a decrease in fruit ${ }^{\circ} \mathrm{h}$, indicating color changes from green to yellow and red, and by an increase in ANT content in healthy fruit without chilling injury symptoms (Figs. 1, 2, 4 and 5). Indeed, the PCA shows that higher ANT content was correlated with lower ${ }^{\circ} \mathrm{h}$ in fruit of both acerola
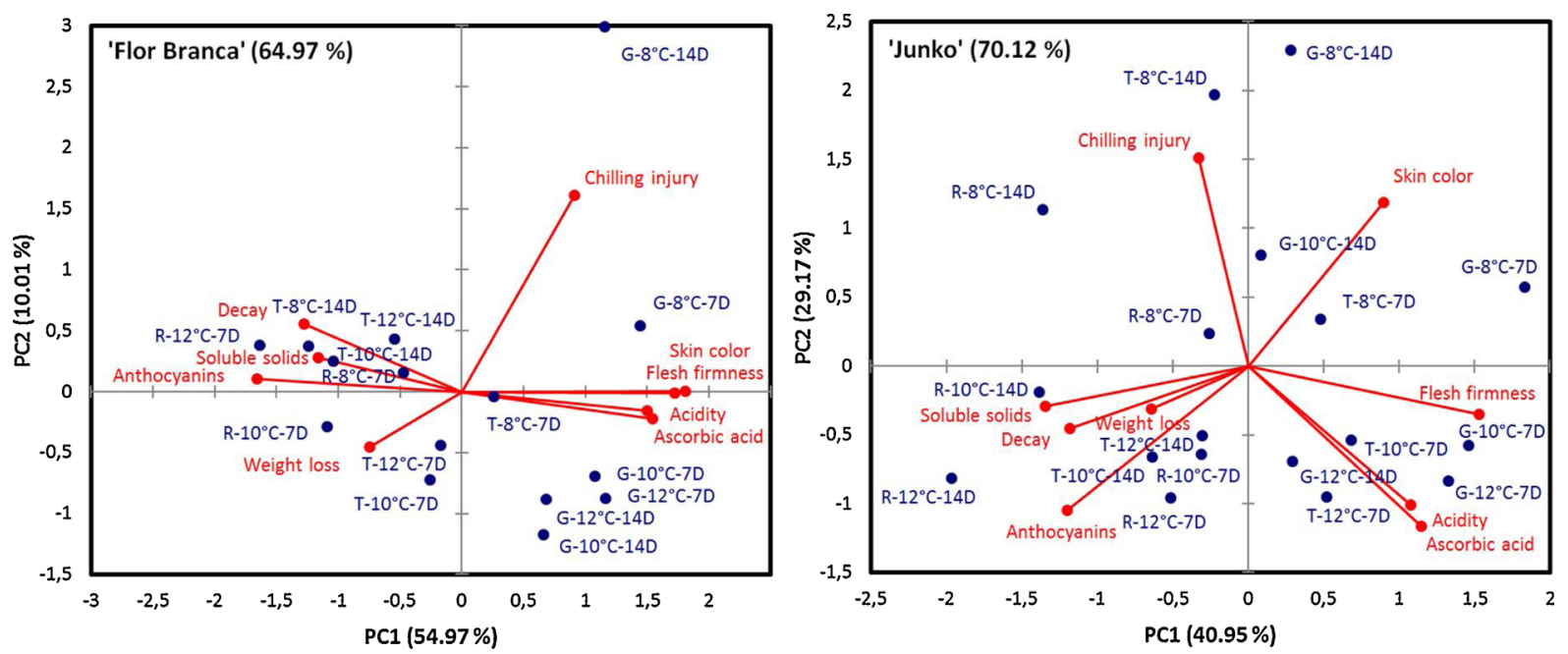

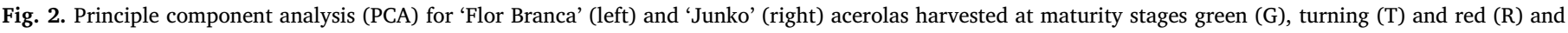
stored at different temperatures $\left(8^{\circ} \mathrm{C}, 10^{\circ} \mathrm{C}, 12^{\circ} \mathrm{C}\right)$ for $7(7 \mathrm{D})$ and 14 days (14D). 


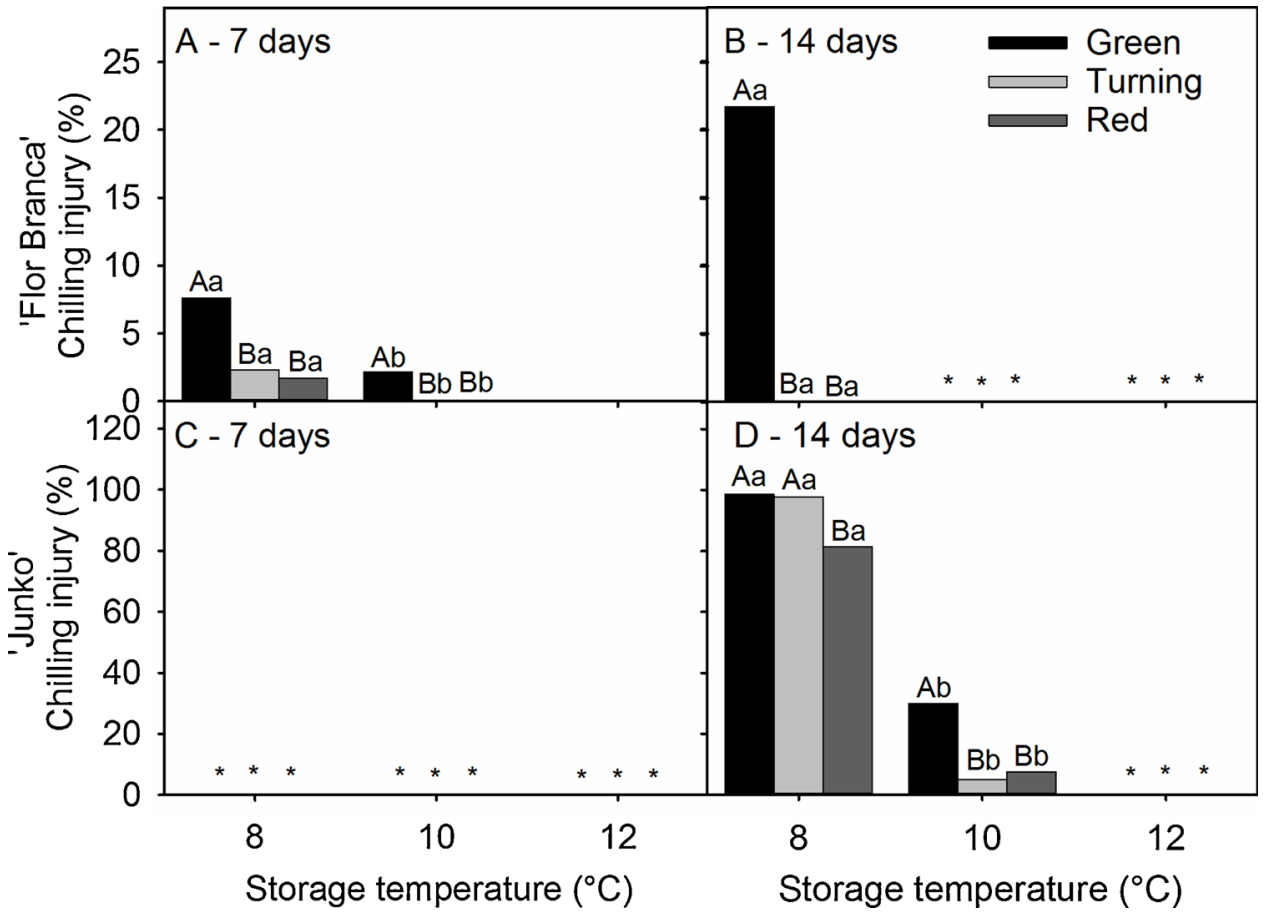

Fig. 3. Chilling injury incidence in 'Flor Branca' and 'Junko' acerolas harvested at maturity stage green (green skin color), turning (initial color changes from green to red) and red (red skin color) and stored at 8, 10 and $12{ }^{\circ} \mathrm{C}$ with $\mathrm{RH}$ of $90-95 \%$ for 7 and 14 days. Upper case letters compare maturity stages within each temperature, lowercase letters compare storage temperatures within each maturity stage. Averages followed by the same letter are statistically equal according to Tukey test (5\%). *Fruit without chilling injury symptoms. cultivars (Fig. 2). These changes were more evident at $12^{\circ} \mathrm{C}$ than at lower temperatures. Storage at 8 and $10^{\circ} \mathrm{C}$ delayed or inhibit ANT synthesis responsible for the red color development in the healthy or chilling injured fruit, respectively. Accordingly, studies have shown that ripening of 'Flor Branca', 'BRS 236' and 'Florida Sweet' acerolas is followed by red color development due to ANT synthesis in the fruit (Oliveira et al., 2012; Souza et al., 2014). Therefore, acerola color change can be used as an indication of fruit ripening capacity after harvest. Studies have shown that mangoes kept at low temperatures exhibited fruit with severe chilling injury symptoms characterized by the inhibition of pigment synthesis and color changes, followed by flesh browning during storage (Miguel et al., 2013). In addition, 'Carabao' mango stored at $4{ }^{\circ} \mathrm{C}$ exhibited a reduction of yellow color development in the skin and flesh tissues, which was attributed to reduced synthesis of carotenoids due to chilling injury (Cantre et al., 2017). Talcott et al. (2005) also reported lower carotenoid synthesis in 'Tommy Atkins' mangoes stored at $5{ }^{\circ} \mathrm{C}$, compared to fruit stored at $20^{\circ} \mathrm{C}$. Although our results show different genotype susceptibility to the disorder, chilling injury symptoms were similar between genotypes starting with the inhibition of anthocyanin synthesis that was followed by the development of water-soaked tissue at more advanced stages.

\subsection{Changes in $A A$ content}

The effect of the interaction between maturity at harvest and storage temperature on AA concentration in the fruit was not significant at

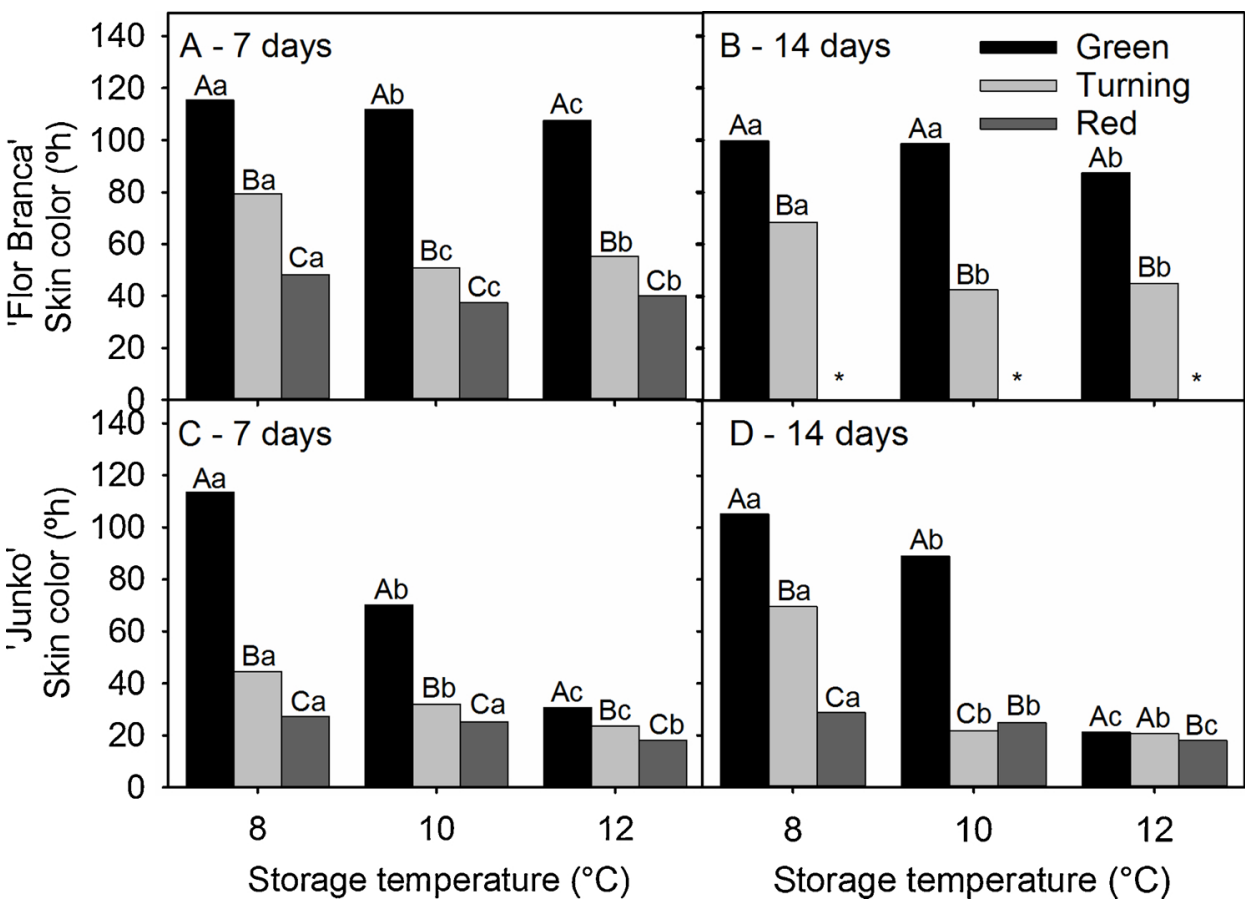

Fig. 4. Skin color of 'Flor Branca' and 'Junko' acerolas harvested at maturity stage green (green skin color), turning (initial color changes from green to red) and red (red skin color) and stored at 8,10 and $12{ }^{\circ} \mathrm{C}$ with $\mathrm{RH}$ of $90-95 \%$ for 7 and 14 days. Upper case letters compare maturity stages within each temperature, lowercase letters compare storage temperatures within each maturity stage. Averages followed by the same letter are statistically equal according to Tukey test (5\%). "Fruit sample showing decay incidence $\geq 60 \%$. 


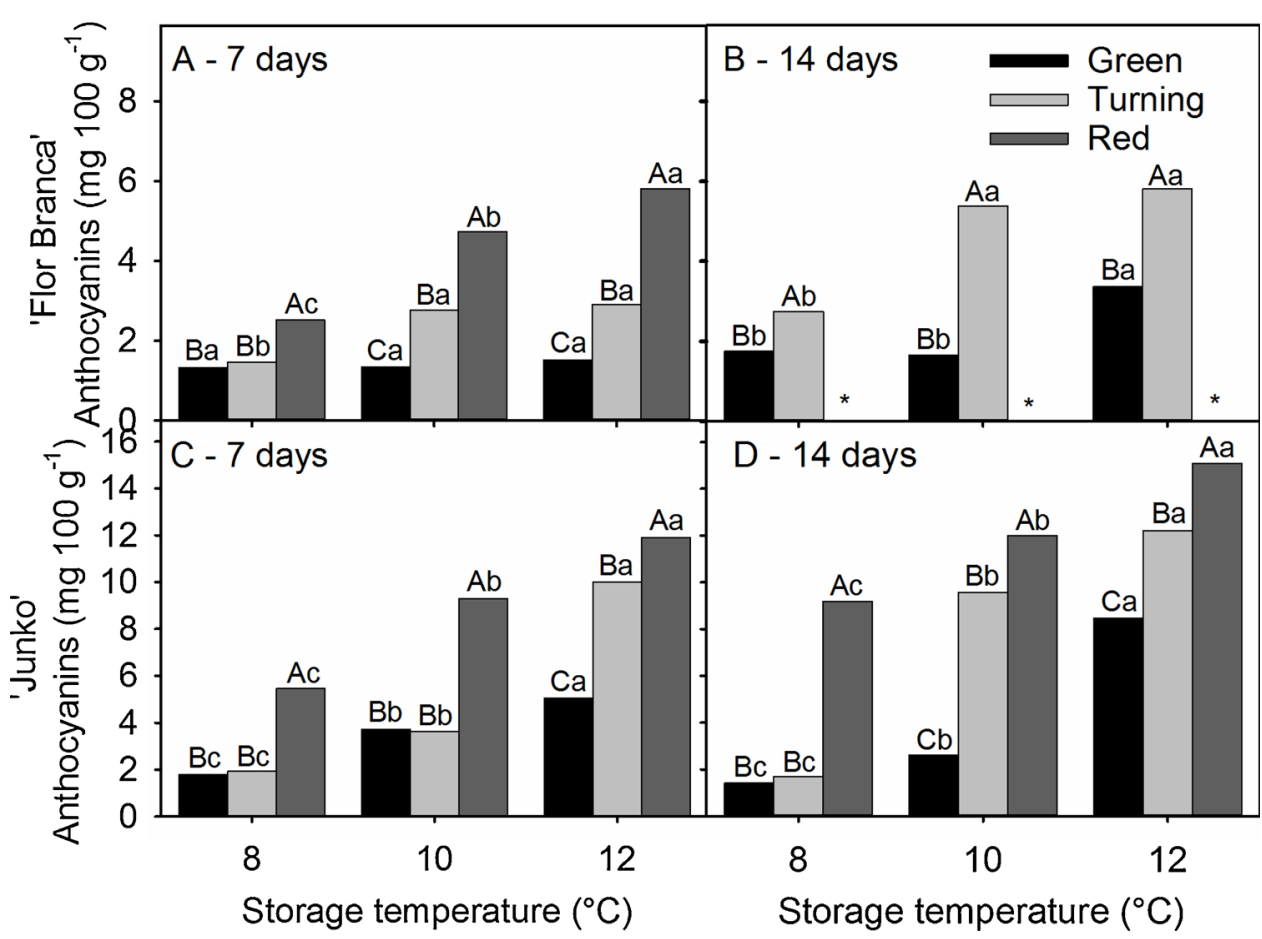

Fig. 5. Anthocyanins content in 'Flor Branca' and 'Junko' acerolas harvested at maturity stage green (green skin color), turning (initial color changes from green to red) and red (red skin color) and stored at 8,10 and $12{ }^{\circ} \mathrm{C}$ with $\mathrm{RH}$ of $90-95 \%$ for 7 and 14 days. Upper case letters compare maturity stages within each temperature, lowercase letters compare storage temperatures within each maturity stage. Averages followed by the same letter are statistically equal according to Tukey test (5\%). *Fruit sample showing decay incidence $\geq$ $60 \%$.

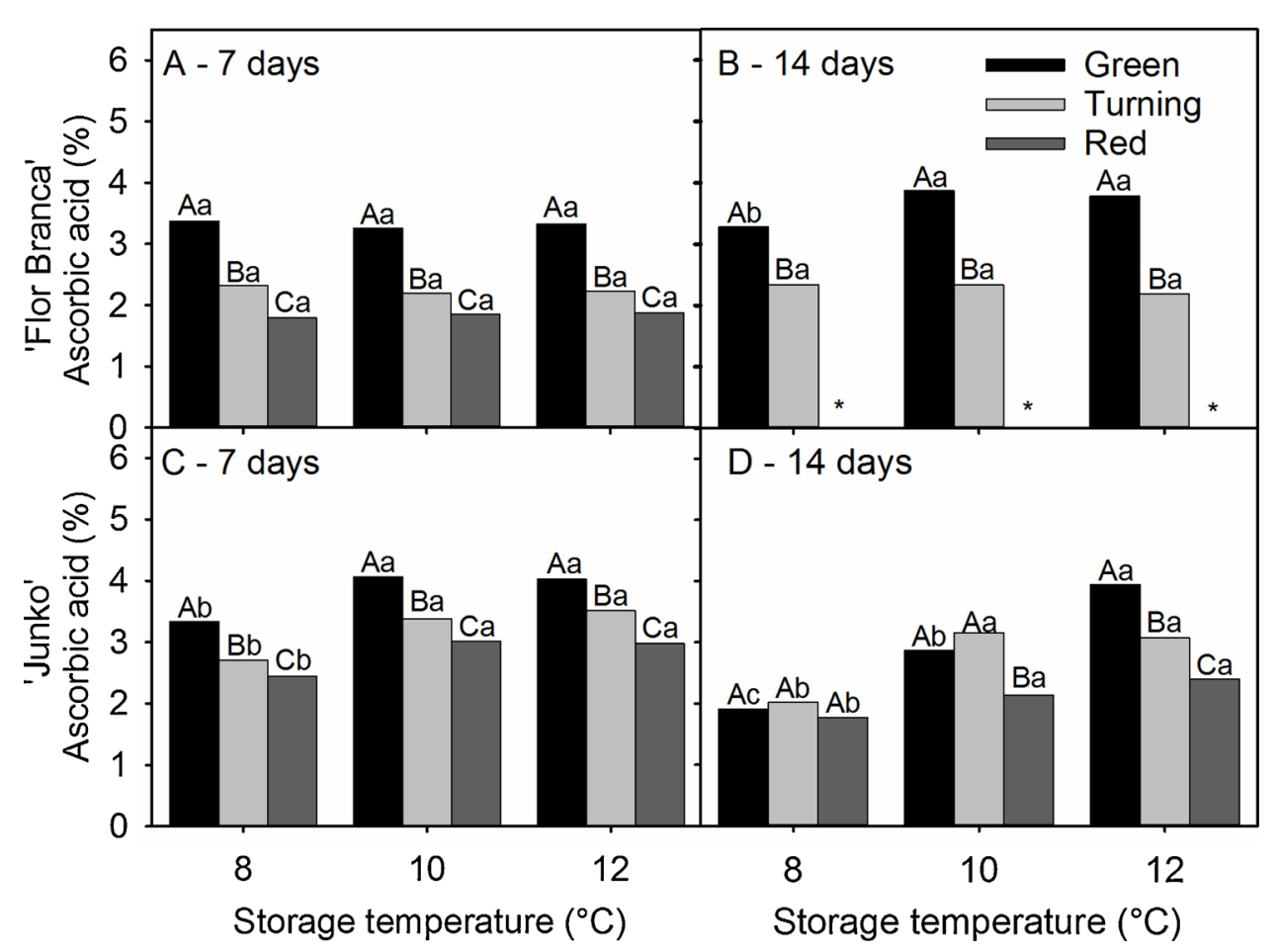

Fig. 6. Ascorbic acid content in 'Flor Branca' and 'Junko' acerolas harvested at maturity stage green (green skin color), turning (initial color changes from green to red) and red (red skin color) and stored at 8,10 and $12{ }^{\circ} \mathrm{C}$ with $\mathrm{RH}$ of $90-95 \%$ for 7 and 14 days. Upper case letters compare maturity stages within each temperature, lowercase letters compare storage temperatures within each maturity stage. Averages followed by the same letter are statistically equal according to Tukey test (5\%). *Fruit sample showing decay incidence $\geq$ $60 \%$.
7 days of storage, but it was significant at 14 days of storage of 'Flor Branca' and 'Junko' acerolas (p-value $<0.001$, Fig. 6). According to the results, acerola ripening was followed by a decrease in AA concentration in the fruit (Fig. 6).

In 'Flor Branca' acerola, the storage temperature had no effect on AA concentration in the fruit after 7 days of storage (Fig. 6). After 14 days, 'Flor Branca' acerola harvested at maturity stage green and stored at $8{ }^{\circ} \mathrm{C}$ showed a reduction of AA concentration, compared to fruit harvested at the same maturity stage and stored at higher temperatures (Fig. 6). 'Junko' acerola harvested at all three maturity stages had lower AA concentration during storage at $8^{\circ} \mathrm{C}$ than during storage at 10 and
$12{ }^{\circ} \mathrm{C}$ for 7 and 14 days (Fig. 6). At 14 days of storage, the highest AA concentration in 'Junko' acerola was observed in fruit harvested at maturity stage green stored at $12{ }^{\circ} \mathrm{C}$ (Fig. 6).

According to the results, fruit with chilling injury symptoms had a marked reduction in AA concentration, which was more expressive in 'Junko' than in 'Flor Branca' acerola. Indeed, the PCA show that chilling injury incidence was negatively correlated with AA content in both acerola cultivars (Fig. 2). Other studies have shown that chilling injury symptoms are also associated with the production of reactive oxygen species (ROS) such as hydrogen peroxide $\left(\mathrm{H}_{2} \mathrm{O}_{2}\right)$, superoxide radicals $\left(\mathrm{O}_{2}{ }^{-}\right)$and hydroxyl (OH-) (Chongchatuporn et al., 2013). ROS have a 
strong effect in the cell by changing normal metabolism through oxidative reactions and by triggering changes at the transcriptome level leading to defense responses (Rice-Evans et al., 1997). High ROS levels lead to lipid peroxidation, loss of membrane structure and function that eventually result in the visual water-soaked symptoms in the tissue (Sevillano et al., 2009). Studies have shown that ROS synthesis and content increase continuously in mangoes showing chilling injury symptoms due to storage at $5{ }^{\circ} \mathrm{C}$ for 25 days. In this study, chilling injured fruit had higher synthesis of $\mathrm{H}_{2} \mathrm{O}_{2}(17.5 \%)$ and $\mathrm{O} 2{ }^{-}{ }^{-}(15.1 \%)$ than healthy fruit (Zhang et al., 2017). In order to counteract the increase in ROS levels, plant tissues have developed different defense lines. One line of defense is the presence and synthesis of antioxidants such as ascorbic acid, vitamins and phenolic compounds (Blokhina et al., 2003; Cai et al., 2011). Another line of defense is related to the activity of antioxidant enzymes such as ascorbate peroxidase (APX). The APX is part of the ascorbate peroxidase cycle that uses ascorbic acid in the ionized form as specific electron donor to reduce $\mathrm{H}_{2} \mathrm{O}_{2}$ to water, reducing the ROS levels in the tissue (Prasad et al., 1997; Huang et al., 2008; Li, 2011). Therefore, in both lines of defense, oxidative stresses lead to reduction of AA levels in the tissue (Apel and Hirt, 2004), which suggests that the observed reduction in AA content in chilling injured acerola was due to the use of ascorbic acid as a defense mechanisms against ROS, mainly during long fruit exposure to chilling conditions.

\subsection{Titratable acidity and soluble solids}

The TA was not influenced by the interaction between harvest maturity and storage temperatures for 'Flor Branca' acerola at 7 and 14 days, as well as for 'Junko' acerola at 7 days of storage (p-value < 0.001, Fig. 7). In 'Flor Branca' acerola, TA was lower in fruit harvested at more advanced maturity stage, presenting no significant difference among storage temperatures at 7 and 14 days of storage (Fig. 7). In 'Junko' acerola, TA was lower in fruit harvested at more advanced maturity stage and in fruit stored at $8{ }^{\circ} \mathrm{C}$ for 7 days. 'Junko' acerola stored for 14 days at $8{ }^{\circ} \mathrm{C}$ showed a reduction in TA with increasing maturity stage at harvest (Fig. 7). According to the PCA, TA follows a similar pattern of AA content in both acerola cultivars, showing that fruit acidity decreases during ripening, following a reduction in the fruit $h^{\circ}$ values (Fig. 2). Our results agree with other studies showing that ripening is followed by the reduction of TA in the fruit (Batista et al., 2000; Adriano et al., 2011; Siddiqui, 2015a, b).

The SS contents were not influenced by the interaction between maturity stage at harvest and storage temperatures for 'Flor Branca' acerolas at 7 and 14 days, presenting higher SS content at the more advanced maturity stage (p-value $<0.001$, Fig. 8). In 'Junko' acerola, SS content were influenced by the interaction between maturity stage at harvest and storage temperature. The highest fruit maturity at harvest resulted in the highest SS content at 7 and 14 days of storage (Fig. 8). The PCA also shows that higher fruit maturity, expressed as higher ANT content, is highly correlated with higher SS content in both acerola cultivars (Fig. 2). After 7 days at 10 and $12{ }^{\circ} \mathrm{C}$, a higher SS content was observed in 'Junko' acerola harvested at maturity stage red (Fig. 8). After 14 days, storage at $12{ }^{\circ} \mathrm{C}$ resulted in lower SS content in 'Junko' acerola harvested at all three maturity stages (Fig. 8). Although our results show limited changes in SS content in acerola fruit harvested at different maturity stage and stored at different temperatures, previous studies have shown similar trends pointing to limited changes in acerola SS content during storage and ripening (Batista et al., 2000; Adriano et al., 2011; Siddiqui, 2015a, b), suggesting that SS content in acerola is very stable after harvest.

\subsection{Flesh firmness}

The flesh firmness was significantly influenced by the interaction between maturity at harvest and storage temperatures for 'Flor Branca' and 'Junko' acerola at 7 and 14 days of storage (p-value $<0.001$, Fig. 9). In both cultivars, fruit harvested at maturity stage green had higher flesh firmness at 7 and 14 days of storage (Fig. 9). At 7 days of storage, fruit of both cultivars harvested at maturity stage green had higher flesh firmness when kept at $8{ }^{\circ} \mathrm{C}$ than at higher temperatures (Fig. 9). The PCA also shows that flesh firmness was negatively correlated with ripening, expressed as ANT content in the fruit of both acerola cultivars (Fig. 2). At 14 days of storage, 'Junko' acerola harvested at all three maturity stages and stored at $12{ }^{\circ} \mathrm{C}$ had higher flesh firmness than fruit stored at lower temperatures (Fig. 9).

The reduction of fruit firmness is the result of changes at the cell

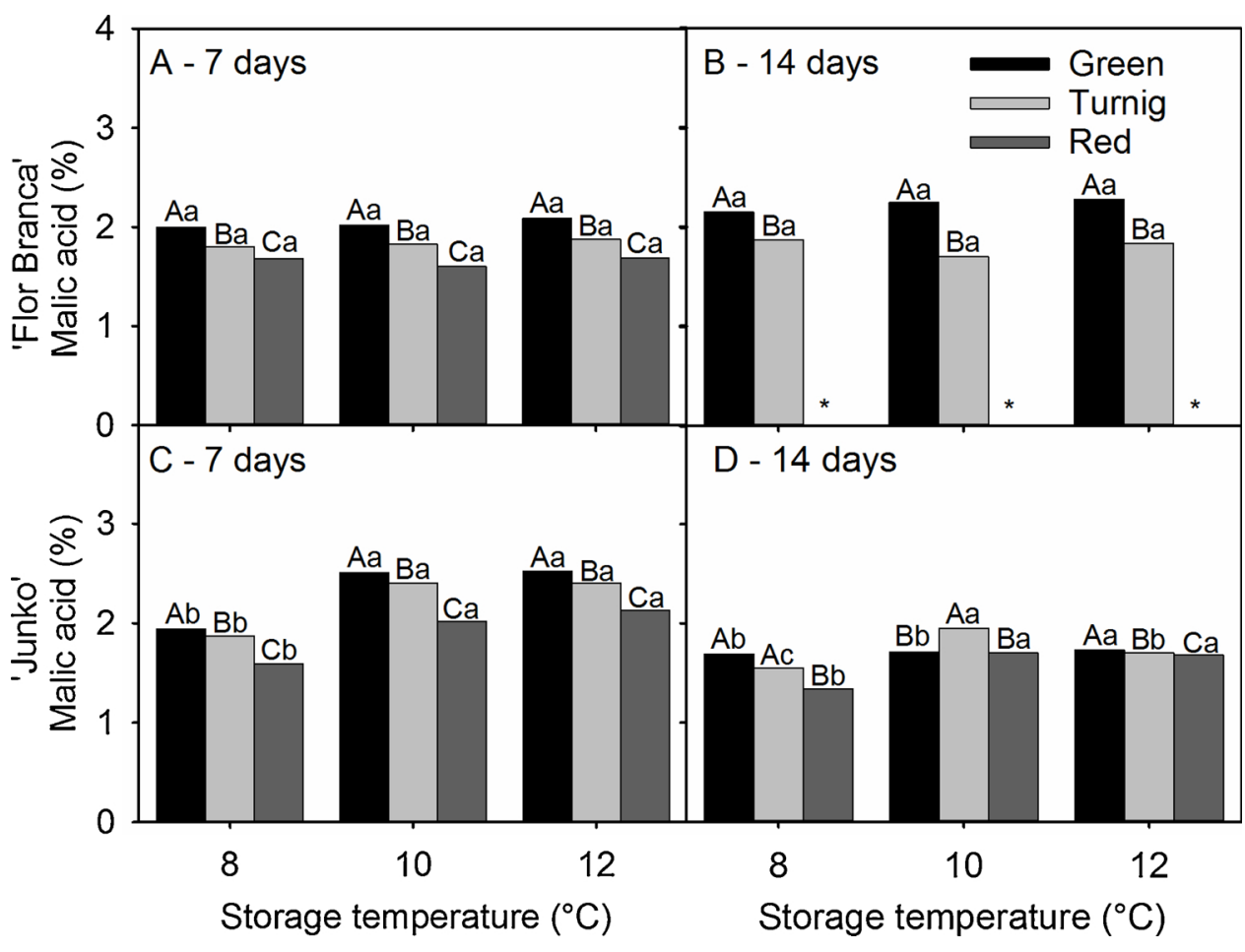

Fig. 7. Malic acid content in 'Flor Branca' and 'Junko' acerolas harvested at maturity stage green (green skin color), turning (initial color changes from green to red) and red (red skin color) and stored at 8,10 and $12{ }^{\circ} \mathrm{C}$ with $\mathrm{RH}$ of $90-95 \%$ for 7 and 14 days. Upper case letters compare maturity stages within each temperature, lowercase letters compare storage temperatures within each maturity stage. Averages followed by the same letter are statistically equal according to Tukey test (5\%). *Fruit sample showing decay incidence $\geq$ $60 \%$. 


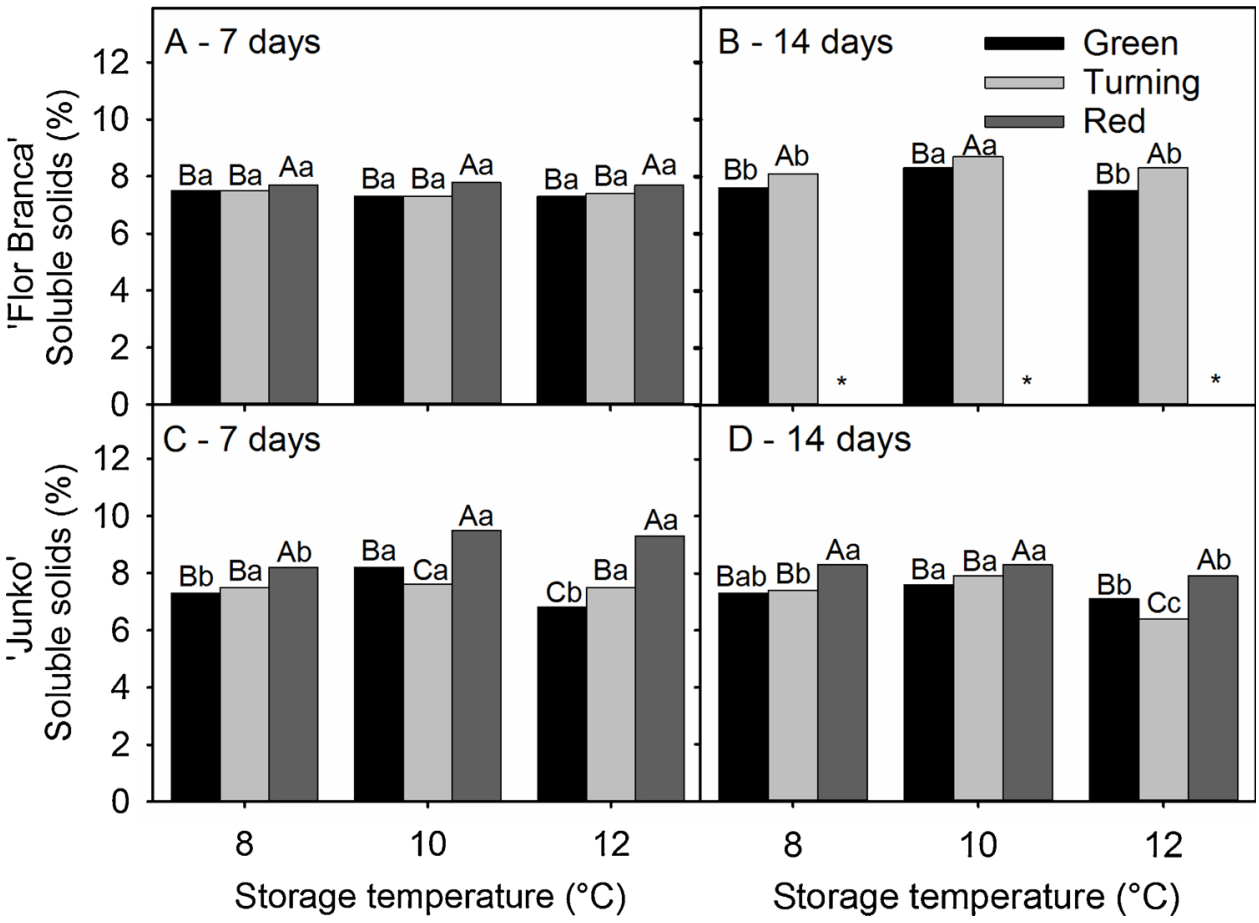

Fig. 8. Soluble solids content in 'Flor Branca' and 'Junko' acerolas harvested at maturity stage green (green skin color), turning (initial color changes from green to red) and red (red skin color) and stored at 8,10 and $12{ }^{\circ} \mathrm{C}$ with $\mathrm{RH}$ of $90-95 \%$ for 7 and 14 days. Upper case letters compare maturity stages within each temperature, lowercase letters compare storage temperatures within each maturity stage. Averages followed by the same letter are statistically equal according to Tukey test (5\%). *Fruit sample showing decay incidence $\geq$ $60 \%$. wall structure and at the cellular turgor pressure during fruit ripening. Cell wall changes are related to the breakdown of cell wall pectins, hemicellulose and cellulose components due to the expression and activity of cell wall degrading enzymes (Silva et al., 2009; Ponce et al., 2010). Cellular turgor pressure changes are related to increasing cellular membrane leakage, loss of cytosolic solutes and water into the apoplasto that leads to loss of turgor pressure (Thomas et al., 2008). Indeed, our results show that acerola fruit harvested at less mature stage maintains higher flesh firmness during storage, which is possibly due to less advanced changes in cell wall breakdown and loss of cellular turgor pressure than observed in softer fruit harvested at more advanced stages. The observed higher flesh firmness in acerola fruit harvested at maturity stage green and stored at $8{ }^{\circ} \mathrm{C}$ for 7 days, compared with fruit harvested at the same maturity stage stored at higher temperature, was not observed at 14 days possibly due to the negative effects of chilling injury on cellular membranes oxidation and breakdown that resulted in loss of turgor pressure and flesh firmness.

\subsection{Decay incidence}

The decay incidence was significantly influenced by the interaction between storage temperatures and maturity stages for 'Flor Branca' acerola at 7 and 14 days, and 'Junko' at 14 days of storage (pvalue $<0.001$, Fig. 10). 'Flor Branca' and 'Junko' acerolas had lower

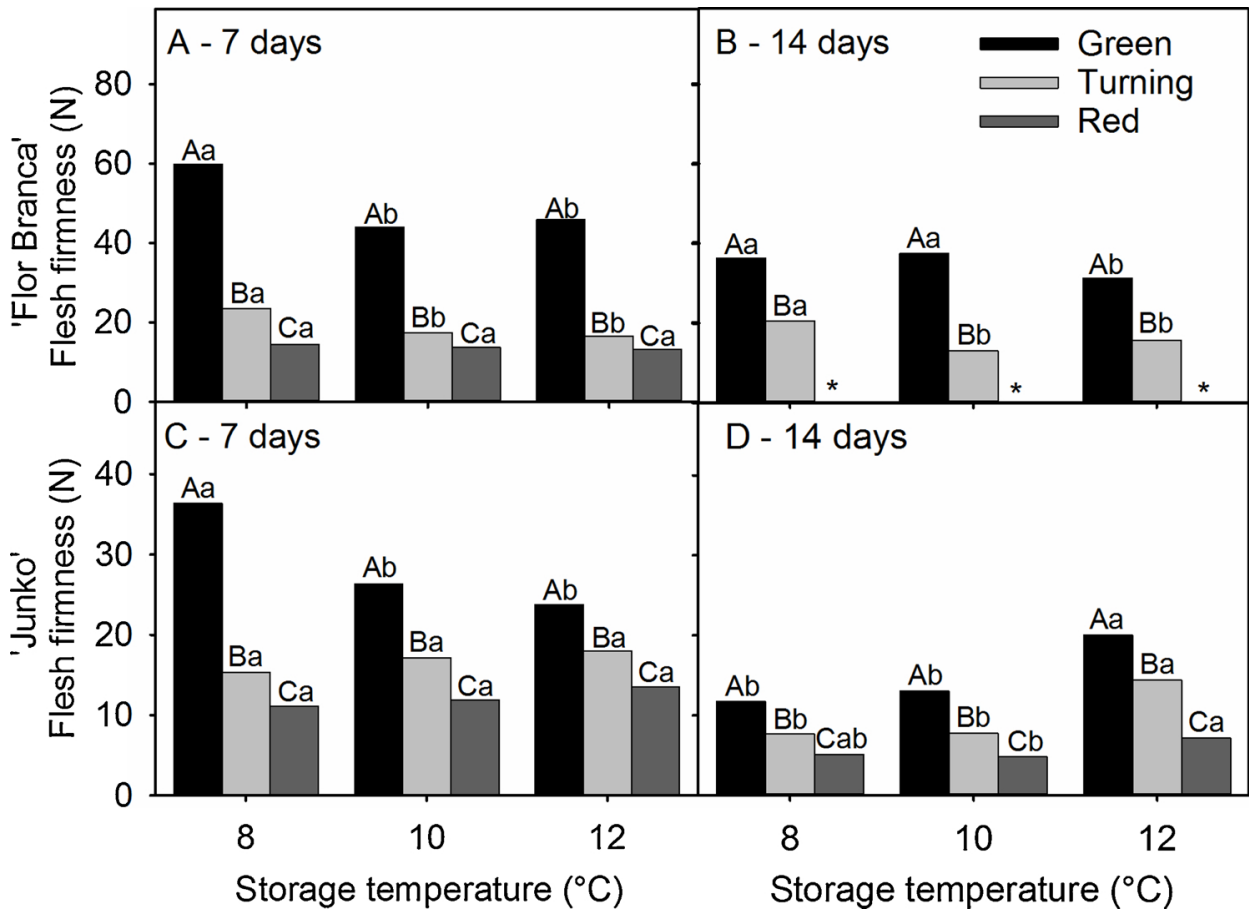

Fig. 9. Flesh firmness of 'Flor Branca' and 'Junko' acerolas harvested at maturity stage green (green skin color), turning (initial color changes from green to red) and red (red skin color) and stored at 8,10 and $12{ }^{\circ} \mathrm{C}$ with $\mathrm{RH}$ of 90-95\% for 7 and 14 days. Upper case letters compare maturity stages within each temperature, lowercase letters compare storage temperatures within each maturity stage. Averages followed by the same letter are statistically equal according to Tukey test $(5 \%)$. *Fruit sample showing decay incidence $\geq 60 \%$. 

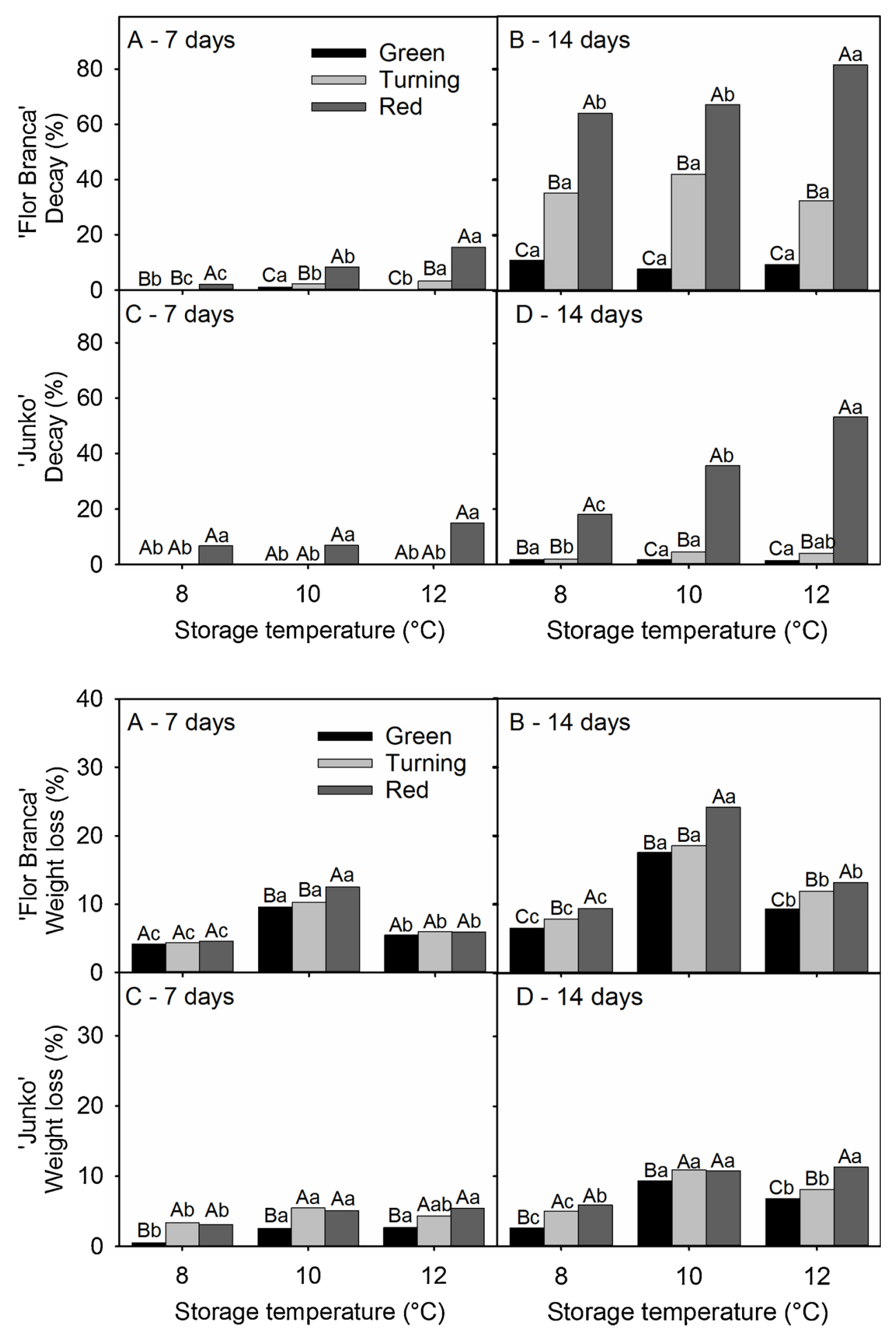

Fig. 10. Decay incidence in 'Flor Branca' and 'Junko' acerolas harvested at maturity stage green (green skin color), turning (initial color changes from green to red) and red (red skin color) and stored at 8,10 and $12{ }^{\circ} \mathrm{C}$ with $\mathrm{RH}$ of 90-95\% for 7 and 14 days. Upper case letters compare maturity stages within each temperature, lowercase letters compare storage temperatures within each maturity stage. Averages followed by the same letter are statistically equal according to Tukey test (5\%). *Fruit sample showing decay incidence $\geq$ $60 \%$.
Fig. 11. Weight loss of 'Flor Branca' and 'Junko' acerolas harvested at maturity stage green (green skin color), turning (initial color changes from green to red) and red (red skin color) and stored at 8,10 and $12{ }^{\circ} \mathrm{C}$ with $\mathrm{RH}$ of 90-95\% for 7 and 14 days. Upper case letters compare maturity stages within each temperature, lowercase letters compare storage temperatures within each maturity stage. Averages followed by the same letter are statistically equal according to Tukey test (5\%). *Fruit sample showing decay incidence $\geq$ $60 \%$. decay incidence in fruit harvested at maturity stages green and turning during storage for 7 and 14 days (Fig. 10). In both cultivars, fruit harvested at the maturity stage red and stored at $12{ }^{\circ} \mathrm{C}$ had the highest decay incidence after 14 days (Fig. 10). At 7 days of storage, decay incidence in 'Junko' acerola was not influenced by the interaction between storage temperatures and maturity stages. At 7 days, storage temperature had no effect on decay incidence in 'Junko' acerolas. The PCA also shows that decay incidence in both cultivars was positively correlated with fruit soluble solids and ANT contents, as well as negatively correlated with fruit red color development, indicating that higher fruit susceptibility to decay is followed by ripening (Fig. 2).
Accordingly, previous studies carried out with blackberry (Palharini et al., 2015), passion fruit (Arruda et al., 2011), persimmon (Brackmann et al., 2006) and guava (Velho et al., 2011) have also shown an increase in decay incidence in response to higher storage temperatures. It has been suggested that fruit susceptibility to decay increases during ripening and senescence due to physical changes, such as loss of cell turgor pressure and cell wall disassembly, as well as due to reduction in the synthesis of chemical defenses in the cells (Siddiqui, 2015a, b; Escobar-Niño et al., 2019). 


\subsection{Weight loss}

The loss of fruit mass was significantly influenced by the interaction between storage temperatures and maturity stages for 'Flor Branca' and 'Junko' acerolas, at 7 and 14 days of storage (p-value $<0.001$, Fig. 11). 'Flor Branca' acerola harvested at all three maturity stages had higher weight loss during storage at $10^{\circ} \mathrm{C}$ than at $8{ }^{\circ} \mathrm{C}$ and $12^{\circ} \mathrm{C}$ (Fig. 11). 'Flor Branca' acerola harvested at maturity stage red and stored at $10{ }^{\circ} \mathrm{C}$ for 7 and 14 days resulted in greater weight loss, reaching more than $20 \%$ after 14 days of storage (Fig. 11). 'Junko' acerola had higher weight loss during storage at all three temperatures for 7 and 14 days if harvested at maturity stages turning and red (Fig. 11). Fruit weight loss is the result of water loss through transpiration and carbon loss through respiration. Therefore, fruit weight loss is closely related to senescence because it compromises visual appearance due to wilting and wrinkling, as well as due to loss of textural quality, juiciness and nutritional value (Azzolini et al., 2004; Vale et al., 2006). According to our results, harvest at the maturity stage green resulted in lower fruit weight loss during 14 days of storage at $12{ }^{\circ} \mathrm{C}$, which was a safe temperature to avoid chilling injury. These results suggest that less mature fruit possibly had lower respiration rates and lower carbon loss during storage. Indeed, the PCA shows that weight loss was negatively correlated with fruit red color in both acerola cultivars, suggesting that higher maturity at harvest can lead to higher weight loss during 14 days of storage (Fig. 2).

\section{Conclusions}

'Flor Branca' and 'Junko' acerolas showed storage potential for up to 14 days, depending on the maturity stage at harvest and storage temperature. Harvest at maturity stage green (green skin color with density lower than $1 \mathrm{~g} \mathrm{~cm}^{-3}$ ) resulted in higher acerola storage potential than harvest at more advanced stages. Storage of 'Flor Branca' acerola at 10 and $12{ }^{\circ} \mathrm{C}$ and 'Junko' acerola at $12{ }^{\circ} \mathrm{C}$ maintained better quality and increased shelf-life of the fruit. Lower temperatures for each cultivar resulted in chilling injury in the fruit, reducing fruit quality and shelflife. In both acerola cultivars, harvest at maturity stage green resulted in lower fruit decay incidence and weight loss during 14 days of storage.

Acerola chilling injury symptoms were characterized by the aqueous and translucent appearance of fruit tissue, as well as strong reduction in AA content and pigment synthesis that resulted on irregular fruit ripening.

\section{Acknowledgment}

The authors would like to thank the funding support from the Brazilian.

\section{References}

Adriano, E., et al., 2011. Qualidade de fruto da aceroleira cv. Olivier em dois estádios de maturação. Revista Brasileira de Fruticultura, v, Especial, pp. 541-545.

Aghdam, S., et al., 2016. Enhancement of postharvest chilling tolerance of anthurium cut flowers by $\gamma$-aminobutyric acid (GABA) treatments. Sci. Hortic. 198, 52-60.

Ancos, B., et al., 2016. Influence of orange cultivar and mandarin postharvest storage on polyphenols, ascorbic acid and antioxidant activity during gastrointestinal digestion. Food Chem.

Apel, K., Hirt, H., 2004. Reactive oxygen species: metabolism, oxidative estress and signal transduction. Annu. Rev. Plant Biol. 55, 373-399.

Araújo, P.G.L., et al., 2009. Qualidade físico-química de frutos de clones de aceroleira recobertos com filme de PVC e conservados por refrigeração. Semin. Ciã̃ncias Agrã jrias 30, 867-880.

Arruda, M.C., et al., 2011. Efeito de produtos químicos e temperaturas de armazenamento na pós-colheita de maracujá-amarelo. Semin. Ciãanncias Agrãjrias 32, 201-208.

Azzolini, M., Jacomino, A.P., Spotto, M.H.F., 2004. Estádios de maturação e qualidade pós-colheita de goiabas 'Pedro Sato'. Revista Brasileira de Fruticultura 26, 29-31.

Batista, M.S., et al., 2000. Parâmetros físicos e químicos da acerola (Malpighia puncifolia, L.) em diferentes fases de maturação. Rev. Bras. Prod. Agroind. 2 (2), 19-24.

Blokhina, O., et al., 2003. Antioxidants, oxidative damage and oxygen deprivation stress: a review. Ann. Bot. 91, 179-194.

Brackmann, A., et al., 2006. Temperaturas para o armazenamento de caquis 'Fuyu'. Revista da FZVA 13, 82-89.

Braman, K., Ahmad, S., Siddiqui, M.W., 2015. Factors affecting the quality of fruits and vegetables. In: Siddiqui, M.W. (Ed.), Postharvest Biology and Technology of Horticultural Crops. CRC Press, Boca Raton, pp. 1-50.

Cai, Y., et al., 2011. Me JA regulates enzymes involved in ascorbic acid and glutathione metabolism and improves chilling tolerance in loquat fruit. Postharv. Biol. Technol. 59, 324-326.

Cantre, D., et al., 2017. Tissue breakdown of mango (Mangifera indica L. Cv. Carabao) due to chilling injury. Postharv. Biol. Technol. 125, 99-111.

Chidtragool, S., et al., 2011. Chilling injury in mango fruit peel: cultivar differences are related to the activity of phenylalanine ammonia lyase. Postharv, Biol. Technol. 62 59-63.

Chitarra, M.I.F., Chitarra, A.B., 2005. Pós-colheita de frutas e hortaliças: Fisiologia e Manuseio, 2. ed. UFLA, Lavras, pp. 783.

Chen, S.W., et al., 2017. Effect of harvest season, maturity and storage temperature on storability of carambola 'Honglong' fruit. Sci. Hortic. 220, 42-51.

Chongchatuporn, U., et al., 2013. Chilling injury in mango (Mangifera indica) fruit peel: relationship with ascorbic acid concentrations and antioxidant enzyme activities. Postharv. Biol. Technol. 86, 409-417.

Crisosto, C.H., et al., 1999. Susceptibility to chilling injury of peach, nectarine, and plum cultivars grown in California. HortScience 34, 1116-1118.

Cunha, K.D., et al., 2014. Estabilidade de ácido ascórbico em sucos de frutas frescos sob diferentes formas de armazenamento. Braz. J. Food Techol. 17, 139-145.

Escobar-Niño, A., et al., 2019. Proteomic study of the membrane components of signaling cascades of Botrytis cinerea controlled by phosphorylation. Sci. Rep. 9, 1-14.

Francis, F.J., 1982. Analysis of anthocyanins. In: MARKAKIS, P. (Ed.), Anthocyanins as Food Colors. Academic Press, New York, pp. 181-207.

Ferreira, E.B., et al., 2013. ExpDes.pt: Experimental Designs Package. Available at http:// cran.r-project.org/package $=$ ExpDes.pt. Access on April 8th, 2019.

huang, R.H., et al., 2008. Effect of salicylic acid on the antioxidant system in the pulp of 'Cara cara' navel orange (Citrus sinensis L. Osbeck) at different storage temperatures. Postharv. Biol. Technol. 47, 168-175.

Li, Q., 2011. Cinnamic acid pretreatment mitigates chilling stress of cucumber leaves through altering antioxidant enzyme activity. J. Plant Physiol. 168, 927-934.

Maciel, M.I.S., et al., 2004. Effects of biofilm and refrigeration on acerola postharvest conservation. Rev. Bras. Frutic. 26, 168-170.

Mangrich, M.E., Saltveit, M.E., 2000. Heat shocks reduce chilling sensitivity of cotton, kenaf, okra, and rice seedling radicles. J. Am. Soc. Hortic. Sci. 125, 377-382.

Mezadri, T., et al., 2006. El fruto de la acerola: composición y posibles usos alimenticios. Archivos Latinoamericanos de Nutrición 56 (2), 101-109.

Mcguire, R.G., 1992. Reporting of objective color measurements. Hortscience 27, 1254-1255.

Miguel, A.C.A., et al., 2013. Qualidade de mangas cv. Palmer após armazenamento sob baixas temperaturas. Rev. Bras. Frutic. 35, 238-408.

Mohammed, M., 2011. Acerola (Malpighia emarginata DC.). In: In: YAHIA, E.M. (Ed.), Postharvest Biology and Technology of Tropical and Subtropical Fruits, vol. 2. Woodhead Publishing Limited, cap, Philadelphia, pp. 27-45.

MUSTAFA, M.A., et al., 2016. Enhancing the antioxidant content of carambola (Averrhod carambola) during cold storage and methyl jasmonate treatments. Postharv. Biol. Technol. 118, 79-86.

Oliveira, L.S., et al., 2012. Antioxidant metabolism during fruit development of different acerola (Malpighia emarginata D.C) clones. J. Agric. Fod Chem. 60, 7957-7964.

Oliveira, E.N.A., Santos, D.C., 2015. Tecnologia e processamento de frutos e hortaliças. Natal: IFRN 234

Palharini, M.C.A., et al., 2015. Efeito da temperatura de armazenamento na conservação pós-colheita de amora-preta. Pesqui. Agropecuãjria Trop. 45, 413-419.

Pan, Y.G., et al., 2017. Effect of low temperatures on chilling injury in relation to energy status in papaya fruit during storage. Postharv. Biol. Technol. 125, 181-187.

Ponce, N.M., et al., 2010. Compositional changes in cell wall polysaccharides from Japanese plum (Prunus salicina Lindl.) during growth and on-tree ripening. J. Agric. Food Chem. 58, 2562-2570.

PRASAD, T.K., et al., 1997. Evidence for chilling induced oxidative stress in maize seedlings and regulatory role for hydrogen peroxide. Plant Cell 6, 65-74.

Qian, C., et al., 2012. Maturity dependent chilling tolerance regulated by the anti oxidative capacity in postharvest cucumber (Cucumis sativus L.) fruits. J. Sci. Food Agric. 93, 626-633.

Qian, C., et al., 2013. Effect of maturity stage on the gene expression of antioxidative enzymes in cucumber (Cucumis sativus L.) fruits under chilling stress. J. Integr. Agric. $12,1495-1500$.

Rekha, C., et al., 2012. Ascorbic acid, total phenol content and antioxidant activity of fresh juices of four ripe and unripe Citrus fruits. Chem. Sci. Trans. 1, 303-310.

R Core Team, 2016. R: A Language and Environment for Statistical Computing. Vienna, Austria: R Foundation for Statistical Computing. Disponível em: < https://www.rproject.org/ > . Acesso em: 16 jun. 2016.

Rice-Evans, C.A., et al., 1997. Antioxidant properties of phenolic compounds. Trends Plant Sci. 2, 152-159.

Ritzinger, R., Ritzinger, C.H.S.P., 2011. Acerola. In: In: Rodrigues, M.G.V., Dias, M.S.C. (Eds.), Cultivo tropical de fruteiras, vol. 32. Informe Agropecuário, pp. 17-25.

Sevillano, L., et al., 2009. Physiological, hormonal and molecular mechanisms regulating chilling injury in horticultural species. Postharvest technologies applied to reduce its impact. J. Sci. Food Agric. 89, 555-573.

Siddiqui, M.W., 2015a. Postharvest Biology and Technology of Horticultural Crops: Principles and Practices for Quality Maintenance. CRC Press, Boca Raton, pp. 572p.

Silva, P.A., et al., 2009. Modificações nas atividades da poligalacturonase e 
pectinametilesterase em morangos armazenados à temperatura ambiente. Ciência e Agrotecnol. 33, 1953-1958.

Siddiqui, M.W., Dhua, R.S., 2010. Eating artificially ripened fruits is harmful. Curr. Sci. 99, 1664-1668.

Siddiqui, M.W., 2015b. Postharvest Biology and Technology of Horticultural Crops: Principles and Practices for Quality Maintenance. CRC Press, Boca Raton, pp. 572p.

Souza, K.Ode, et al., 2014. Antioxidant compounds and total antioxidant activity in fruits o acerola from cv. Flor Branca, Florida sweet and BRS 366. Rev. Bras. Frutic. 36, 294-304.

Strohecker, R., Henning, H.M., 1967. Análises de vitaminas: métodos comprovados. Paz Montolvo, Madrid, pp. 428p.

Talcott, S.T., et al., 2005. Ripening associated phytochemical changes in mangos (Mangifera indica) following thermal quarantine and low-temperature storage. J. Food Sci. 70, 337-341.

Thomas, T.R., et al., 2008. Mesocarp cell turgor in Vitis vinifera L. Berries throughout development and its relation to firmness, growth, and the onset of ripening. Planta 228, 1067-1076.

Vale, A.A.S., et al., 2006. Alterações Químicas, Físicas e Físico-Químicas da Tangerina
'Ponkan' (Citrus reticulata Blanco) Durante o Armazenamento Refrigerado. Ciência e Agrotecnologia 30, 778-786.

Velho, A.C., et al., 2011. Influência da temperatura de armazenamento na qualidade póscolheita de goiabas serranas. Revista Brasileira de Fruticultura 33, 014-020.

Vendramini, A.L., TRUGO, L.C., 2000. Chemical composition of acerola fruit (Malpighia punicifolia L.) at three stages of maturity. Food Chem. 71, 195-198.

Wang, C.Y., 2009. Chilling injury of fruits and vegetables. Food Reviews International. WANG, C. Y (1989) Chilling injury of fruits and vegetables. Food Rev. Int. 5, 209-236.

Yahia, M.E., 2011. 1. ed. Postharvest Biology and Technology of Tropical and Subtropical Fruits: Açai to Citrus, vol. 2. Woodhead Publishing Limited, Cambridge, pp. 27-45.

Zhang, Z., et al., 2017. Low-temperature conditioning induces chilling tolerance in stored mango fruit. Food Chem. 219, 76-84.

Zhao, Z., et al., 2009a. A Maturity-related chilling tolerance in mango fruit and the antioxidant capacity involved. J. Sci. Food Agric. 89, 304-309.

Zhao, D.Y., et al., 2009b. B Physiological and genetic properties of tomato fruits from 2 cultivars differing in chilling tolerance at cold storage. J. Food Sci. 74. 